\title{
Belgeo
}

Revue belge de géographie

$1 \mid 2021$

Miscellaneous

\section{Detection of recent changes in Gambia vegetation cover using time series MODIS NDVI}

Détection des modifications récentes de la couverture végétale en Gambie à

l'aide d'une série temporelle d'images MODIS NDVI

Boubacar Solly, Aruna M. Jarju, Ebrima Sonko, Sidat Yaffa and Mamma Sawaneh

\section{OpenEdition}

\section{Journals}

Electronic version

URL: https://journals.openedition.org/belgeo/47995

DOI: 10.4000/belgeo.47995

ISSN: 2294-9135

Publisher:

National Committee of Geography of Belgium, Société Royale Belge de Géographie

\section{Electronic reference}

Boubacar Solly, Aruna M. Jarju, Ebrima Sonko, Sidat Yaffa and Mamma Sawaneh, "Detection of recent changes in Gambia vegetation cover using time series MODIS NDVI", Belgeo [Online], 1 | 2021, Online since 03 June 2021, connection on 24 October 2021. URL: http://journals.openedition.org/belgeo/ 47995 ; DOI: https://doi.org/10.4000/belgeo.47995

This text was automatically generated on 24 October 2021

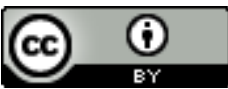

Belgeo est mis à disposition selon les termes de la licence Creative Commons Attribution 4.0 International. 


\title{
Detection of recent changes in Gambia vegetation cover using time series MODIS NDVI
}

\author{
Détection des modifications récentes de la couverture végétale en Gambie à \\ l'aide d'une série temporelle d'images MODIS NDVI \\ Boubacar Solly, Aruna M. Jarju, Ebrima Sonko, Sidat Yaffa and Mamma \\ Sawaneh
}

\section{Introduction}

In West Africa, particularly in The Gambia, vegetation cover has undergone significant changes over the past five decades (Ariori and Ozer 2005; FAO, 2015; CILSS, 2016; Diedhiou et al., 2020) in relation to climate variability and human actions. The former is commonly indexed as the main driver of vegetation change in West Africa (Herrmann et al., 2005). It determines the zoning of the vegetation cover and the amount of plant biomass. Its role in changes in vegetation cover has been demonstrated several times (Philippon et al., 2008; Hountoudji, 2008; Cisse, 2016). However, climatic variability marked by decreasing rainfall and increasing temperature has been noted in The Gambia since the drought years, that is to say the years 1970-80 (Sanneh et al., 2013; Diedhiou, 2019). For the second, it is about agricultural land clearing, firewood and charcoal cutting, overgrazing, and the advance of the urban front (Diedhiou, 2019; Bah et al., 2019; Fent et al., 2019).

2 Thus, in order to participate in the production of knowledge in achieving Goal 15 of the Sustainable Development Goals on the preservation and restoration of terrestrial ecosystems, monitoring of changes in vegetation cover is necessary. For a State such as The Gambia and for the United Nations Development Program (UNDP), such monitoring is a major interest for better resource and environmental management. This monitoring takes on a particularly interesting dimension through the identification, description and analysis of the ongoing process. It is all the more interesting 
considering that the literature on the issue throughout the Republic of The Gambia is very little, if not scarce. Most of the studies conducted there have focused on adaptation to climate change and agricultural production (Akon-Yamga et al., 2011; Yaffa, 2013; Sanneh et al., 2014; Sonko et al., 2019; Jarju et al., 2021). A few rare studies have focused on the dynamics of land use and changes in vegetation cover both in wetlands and land, either at the zonal, regional or national scale (Andrieu and Mering, 2008 ; CILSS, 2014; Diedhiou, 2019; Bah et al., 2019; Fent et al., 2019; Diedhiou et al., 2020; Dieye et al., 2021). Studies carried out at the West African or Sahel scale have paid little attention to the analysis of results at The Gambia scale (Herrmann et al., 2005; Dardel et al., 2014; Leroux et al., 2014; Brandt et al., 2016).

3 Techniques for monitoring recent changes in vegetation cover at the national or West African band level includes remote sensing, through the analysis of trends in time series of MODIS images, is positioned as an effective means (Andrieu, 2018; Zoungrana et al., 2018; Gansaonre et al., 2020). These time series provide the most appropriate data for analyzing the trend of changes related to natural and human phenomena (Hamimina et al., 2013). Using the Normalized Difference Vegetation Index (NDVI), they identify land degradation and regeneration (Eckert et al., 2015; Solly et al., 2021). This index provides information on photosynthetic activity, leaf water content, soil moisture, phytosanitary quality, primary productivity, biomass, etc. It can detect changes in vegetation productivity through changes in vegetation cover (Guo et al., 2018). In addition, it is strongly correlated with rainfall in many West African countries (San Emeterio et al., 2011), especially in areas that record less than $1000 \mathrm{~mm}$ per year (Nicholson et al., 1990). Differences or changes in species types, the presence of disturbed vegetation in an area with a similar vegetation type, and evolutionary factors may also be reflected through NDVI (Yengoh et al., 2015).

4 The objective of this study is therefore to determine changes in vegetation cover in The Gambia, through the use of time series of NDVI MODIS images over the period 2000-2019.

\section{Study area}

The Republic of The Gambia is located in the West African zone between latitudes $13^{\circ} 30$ and $13^{\circ} 49 \mathrm{~N}$ and longitudes $16^{\circ} 48$ and $13^{\circ} 47$. Except on the Atlantic coast, the country is bordered on all sides by the Republic of Senegal. The country is about $480 \mathrm{~km}$ long and varies in width from $48 \mathrm{~km}$ in the river estuary to $24 \mathrm{~km}$ inland (Ministry of Environment, 2018). It covers an area of 11,259 sq.km spread over six administrative regions (Fig. 1). 
Figure 1. Location of the study area.

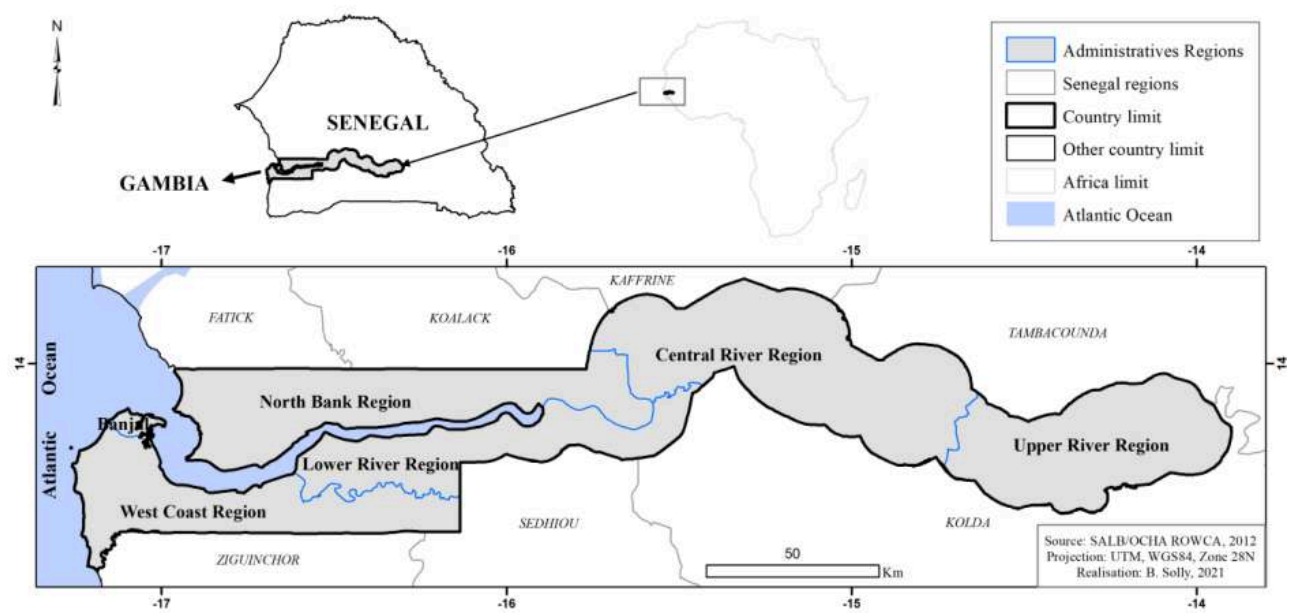

6 Land use and land cover are composed of 14 main classes: forest, gallery forest, woodland, mangrove, savannah, wooded to shrub savannah, cultivation areas, irrigated crops, plantations, settlements, bare soils, sandy surfaces, water bodies and swampy and floodplain grasslands (CILSS, 2016; Ministry of Environment, 2018). From a climatic point of view, the year is characterized by two seasons. The dry season, which usually starts from November to May, and the rainy season from June to October. Average annual rainfall varies from 600 to $900 \mathrm{~mm}$, and seasonal temperatures vary between $32 \mathrm{C}$ and $34^{\circ} \mathrm{C}$ and are generally higher in the eastern part of the country (Loum and Fogarassy 2015; Bojang et al., 2016). The population is estimated at 1,867,000 inhabitants in 2013 and is mainly concentrated in the Greater Banjul Area, with 1,390,000 inhabitants in 2016 (CIESIN, 2005). The main economic activities revolve around agriculture (rice, maize and peanut), cutting and marketing of firewood and service, and fishing. These are also the main activities that affect the development of vegetation cover in The Gambia.

\section{Data and method}

\section{Data used}

7 To detect changes in vegetation cover in The Gambia, we used MODIS NDVI data. The MODIS satellite has the advantage of providing images over 16 days available since the second half of February 2000 with a spatial resolution of $250 \mathrm{~m}$. In terms of the long NDVI time series ( $>10$ years), it is the most spatially resolved series that exists today. Compared to NOAA AVHRR data, MODIS data showed better performance for such a study (Fensholt, 2004). The images are uploaded to https://search.earthdata.nasa.gov/ as granules. The products are provided in the Hierarchical Data Format for NASA's Earth Observing System (HDF-EOS) format and are composed of several bands, including NDVI. The series used here runs from 2000 to 2019, from version 6 of the vegetation indices of the Terra medium resolution imaging spectrometer (product MOD13Q1). 


\section{Treatment method}

The methodological approach began with the creation of the time series (TSF) from the module "Earth Trends Modeler" on Idrisi TerrSet, using all the images (2000-2019). After this step, we corrected the images by replacing the erratic values (especially related to clouds and missing lines) with interpolated values using the Preprocess function (Denoise).

9 We then calculated the correlation of Kendall or Kendall's tau through linear regression, first on the 227 NDVI values (23 syntheses x 10 years) for the period 2000-2009, then on the 230 NDVI values for the period 2010-2019, and finally on the 457 NDVI values for the period 2000-2019 (Solly et al., 2021). Two parameters were considered here. This is the correlation coefficient "tau" and the significance " $p$ ". The correlation coefficient (s) highlights the trend in the vegetation index. It is given by equation 1 and 2:

$$
S=\sum_{i=1}^{x-1} \sum_{j=i+1}^{x} \operatorname{sign}\left(x_{1}-x_{1 j}\right)
$$

and

$$
\operatorname{sign}\left(x_{i}-x_{j}\right)=\left\{\begin{array}{l}
1 i f x_{1}-x_{j}<0 \\
0 i f x_{1}-x_{j}=0 \\
-1 i f x_{1}-x_{j}>0
\end{array}\right.
$$

where $\mathrm{n}$ is the length of the data series studied, and the observations made on date, $i$ and $j$ respectively. For all $i=n j=n-1$.

The Kendall trend rate $(\tau)$ is obtained through equation 3:

$$
\tau=\frac{2 s}{n(n-1)}
$$

with $\mathrm{s}$ the correlation coefficient of Kendall and $\mathrm{n}$ the length of the series of data studied.

The correlation coefficient varies between -1 and +1 , and measures the relationship between two sets of variables to determine the degree to which a trend increases, decreases or remains unchanged (Wessels et al., 2012).

The estimation of the significance of the correlation "tau" is given by equation 4 :

$$
p=2[1-\emptyset(|Z|)]
$$

$15 \mathrm{Z}$ follows a standard normal distribution, and a positive value of $\mathrm{Z}$ means an upward trend, and a negative value means a downward trend.

The significance value highlights the significance of the trend (Neeti and Eastman 2011) in that it represents the measure of the need to reject a null hypothesis $(p=0)$. The threshold used here for the test is $10 \%(\mathrm{p}<0.1)$. It may vary by author by 0.1 (Andrieu, 2018; Solly et al., 2021) to 0.001 (Neeti and Eastman, 2011) to 0.01 (Mishra and Mainali, 2017), and 0.05 (Eckert et al., 2015; Zoungrana et al., 2018; Guo et al., 2018; Gansaonre et 
al., 2020), and according to the estimator used (p, slope TS, Z, TS Intercept). The $0.1 \%$ threshold is used here because, at $0.05 \%$ which is the most used, we have almost no significance in the trends. In this study the estimator used is $p$.

The result made it possible to detect the different trends (positive and negative) of the NDVI and their significance, presented in the rest of the work. A positive value indicates an upward trend while a negative value indicates a downward trend. The trend is significant positive when $\geq 0.1$; significant negative when $\leq-0.1$.

\section{Results}

\section{Vegetation trends in The Gambia between 2000 and 2009}

During the decade 2000-2009, the average Kendall correlation generally indicates a positive trend of NDVI on $98.37 \%$ of the study area. However, this trend is not significant (Fig. 2). Correlation values range from 0.2 to -0.15 .

Figure 2. (a) Trends in NDVI between 2000 and 2009; (b) Significance of $p$ at 10\% threshold.
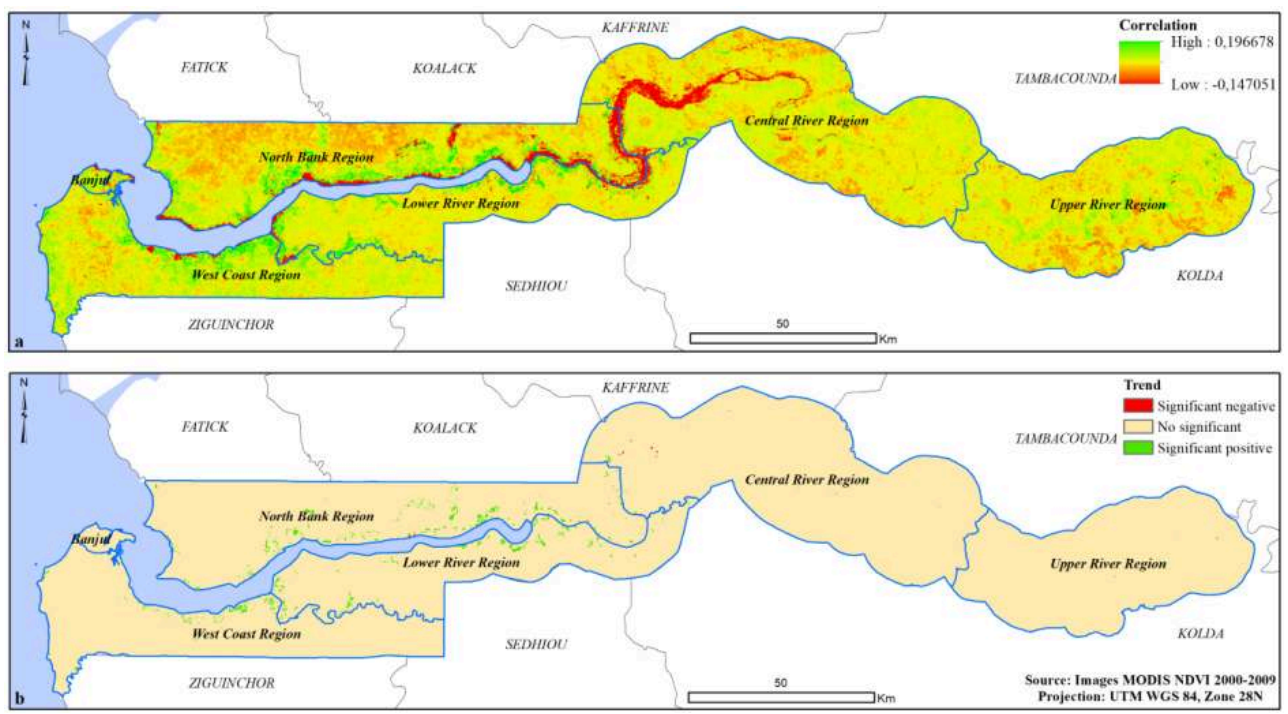

From a spatial perspective, positive correlation values are observed in all administrative regions. The southern part of the North Bank Region and the northern part of the West Coast Region and the Lower River Region had the most significant positive correlations with a significant trend at $\mathrm{p} \geq 0.1$. Otherwise, negative but not significant correlations values were also observed. In these three regions, the positive trends represent $20.33 \%, 16.21 \%$ and $13.82 \%$ respectively (Table 1 ).

Table 1. Trends in NDVI by region (in percentage) between 2000 and 2009.

\begin{tabular}{|l|l|l|}
\hline Regions & Positive trend & Negative trend \\
\hline Banjul & 0,62 & 0,05 \\
\hline West Coast Region & 16,21 & 0,12 \\
\hline
\end{tabular}




\begin{tabular}{|l|l|l|}
\hline North Bank Region & 20,33 & 0,86 \\
\hline Lower River Region & 13,82 & 0,15 \\
\hline Central River Region & 27,89 & 0,46 \\
\hline Upper River Region & 19,48 & 0,00 \\
\hline Total by trend & 98,37 & 1,63 \\
\hline Total all trends & $\mathbf{1 0 0}$ & \\
\hline
\end{tabular}

However, more than a quarter of the positive trends in vegetation productivity in the Republic of The Gambia during this decade are recorded in the Central River Region, although this is also the region with the most pixels of significant negative trends. The percentage of significant positive trend (at the $10 \%$ threshold) is $1.57 \%$. The significant negative trend is $0.04 \%$ and is mainly observed in the northeastern part of the Central River Region.

\section{Vegetation trends in The Gambia between 2010 and 2019}

During the decade 2010-2019, we generally see a decreasing trend in vegetation productivity (Fig. 3a) compared to the decade 2000-2009, but not significant in the pValue test (Fig. 3b). Only a few pixels with a significant positive trend are observed; they are dispersed throughout all administrative regions except the West Coast Region. This region was also the one with the largest increase in NDVI with $13.87 \%$ of the study area (Table 2).

Figure 3. (a) Trends in NDVI between 2010 and 2019; (b) Significance of $p$ at 10\% threshold.
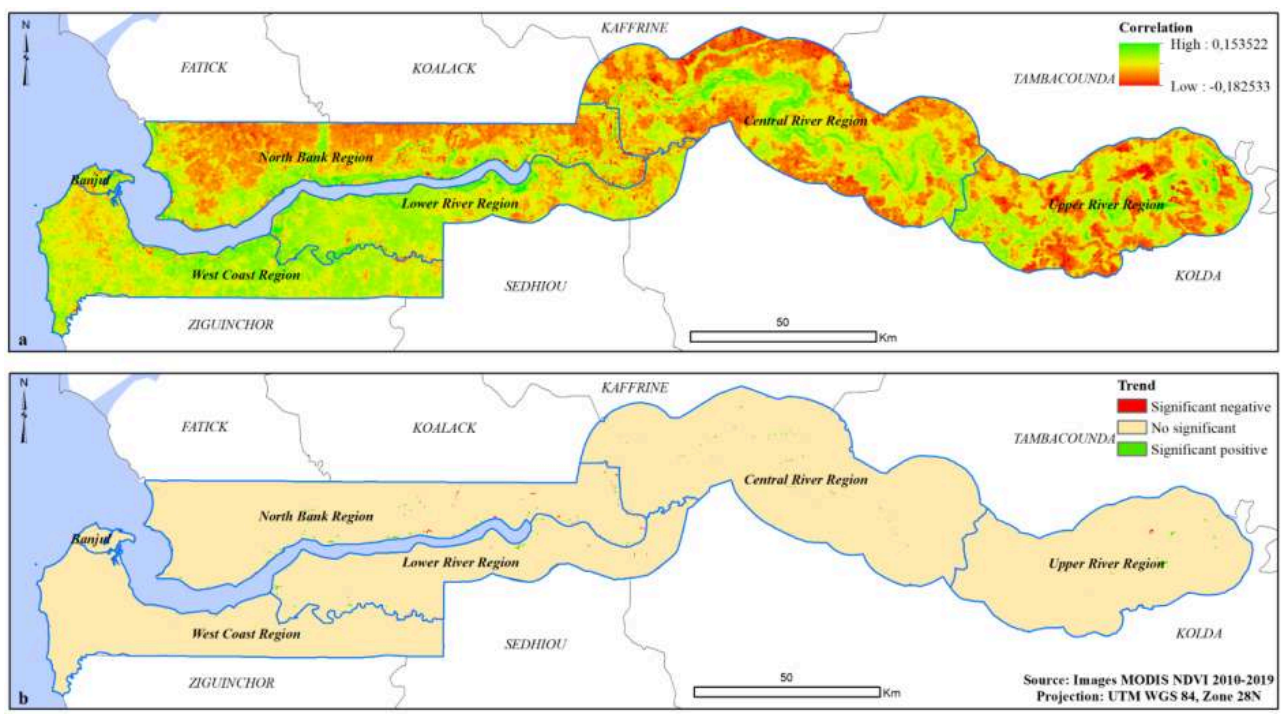

During this decade the correlation values vary between +0.15 and -0.18 . The percentage of positive correlation is $56 \%$, and the percentage of negative correlation is $44 \%$. The 
latter mainly concerns the North Bank Region (with 12.87\%) and the Central River Region (with 15.7\%).

Table 2. NDVI Trends by Region (Percent) Between 2010 and 2019.

\begin{tabular}{|l|l|l|}
\hline Regions & Positive trend & Negative trend \\
\hline Banjul & 0.45 & 0.22 \\
\hline WestCoast Region & 13.87 & 2.45 \\
\hline North Bank Region & 8.28 & 12.87 \\
\hline Lower River Region & 10.84 & 3.14 \\
\hline Central River Region & 12.68 & 15.7 \\
\hline Upper River Region & 9.87 & 9.63 \\
\hline Total by trend & 55.99 & 44.01 \\
\hline Total all trends & $\mathbf{1 0 0}$ & \\
\hline
\end{tabular}

\section{Vegetation trends in The Gambia between 2000 and 2019}

During these two decades, the average of the Kendall correlation indicates that $61.86 \%$ of the national territory is marked by a positive trend and $38.14 \%$ by a negative trend (Fig. 4a; Table 3). However, the southern part of the North Bank Region, and the northern part of the West Coast Region and the Lower River Region, are the ones that have recorded the strongest trends in increasing vegetation productivity. These trends are also significant overall at the $\mathrm{p}$ test (figure $4 \mathrm{~b}$ ). The Central River Region also recorded a significant positive trend in NDVI. 
Figure 4. (a) Trends in NDVI between 2000 and 2019; (b) Significance of $p$ at 10\% threshold.
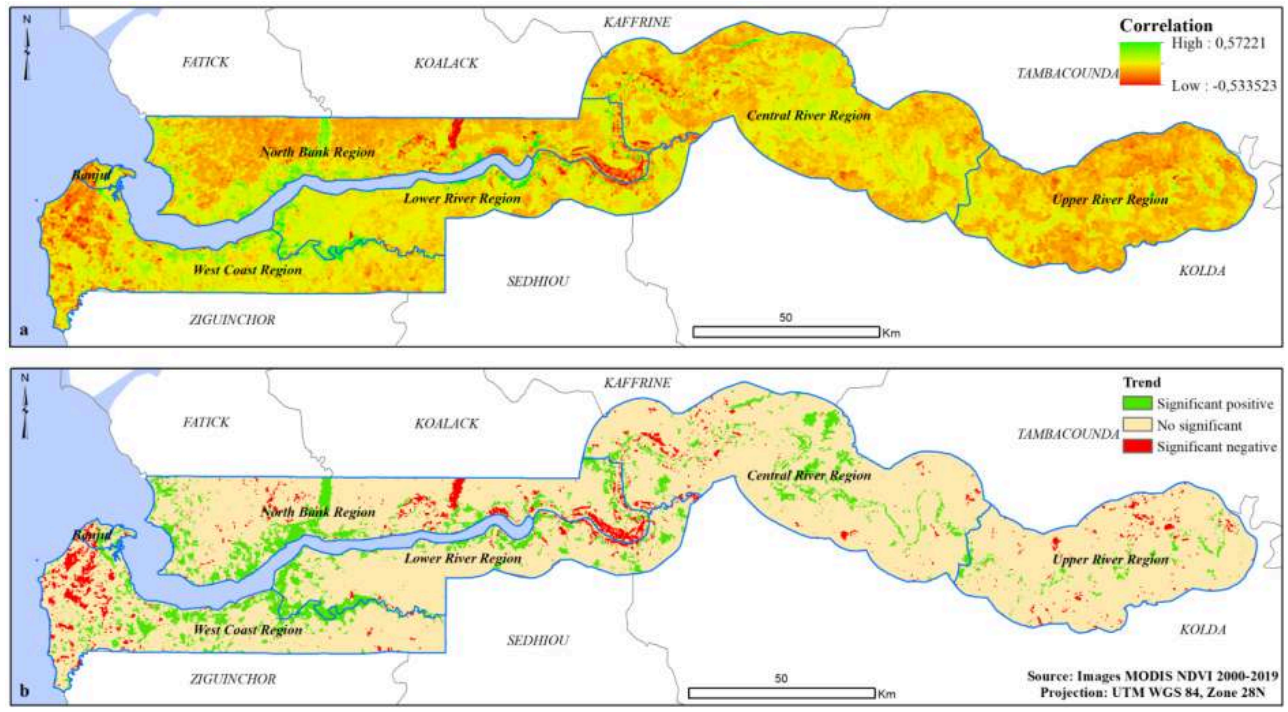

However, in the north-western part of the Central River Region, we notice large pixels of significant negative values. The same is true in the western part of the West Coast Region and Banjul, at the eastern end of the North Bank Region along the river and the Upper River Region. Lower River Region had the lowest negative NDVI trends (2.69\% of the study area). For Banjul and the North Bank Region, the percentage of positive trends is relatively equal to the negative percentages.

Table 3. NDVI Trends by Region (Percent) Between 2000 and 2019.

\begin{tabular}{|l|l|l|}
\hline Regions & Positive trend & Negative trend \\
\hline Banjul & 0.34 & 0.32 \\
\hline West Coast Region & 11.39 & 4.94 \\
\hline North Bank Region & 10.24 & 10.87 \\
\hline Lower River Region & 11.32 & 2.69 \\
\hline Central River Region & 17.52 & 10.87 \\
\hline Upper River Region & 11.05 & 8.45 \\
\hline Total by trend & 61.86 & 38.14 \\
\hline Total all trends & $\mathbf{1 0 0}$ & \\
\hline
\end{tabular}

In sum, over the last 20 years, the percentage of significant negative trend is $4 \%$ and the positive $10 \%$ at the $10 \%$ threshold. 


\section{Discussion} Banjul would be the main factor explaining (CIESEN, 2005) the significant downward trend in NDVI noted especially in the west façade between 2000 and 2019. This situation shows the importance of the degradation of the vegetation cover in this area; hence the urgency for the Gambian authorities to act. In fact, in these two administrative regions, Diedhiou (2019) had reported an increase in very open woodlands at the expense of denser formations which can be seen as an indicator of the importance of pressures on forest resources.

In addition to the results on a thematic level, methodologically, this study showed the importance of the approach used to study changes in vegetation cover. Indeed, using the contextual test of Mann-Kendall, Neeti and Eastman (2011) obtained a very significant result in the detection of trends in relatively short time series. Using Kendall's correlation test or Kendall's "tau" for vegetation kinematics in Ivory Coast (Andrieu, 2018) and for detecting areas of degradation and regeneration of vegetation cover in southern Senegal (Solly et al., 2021), these authors obtained significant correlations at $\mathrm{p}<0.1$. This threshold used in this study also provided us with 
satisfactory results. However, it should be noted that trends may vary depending on the series used; this is why it is important to interpret the results carefully.

\section{Conclusion}

Changes in land cover are often used as indicators of land degradation or regeneration. Thanks to a time series of MODIS NDVI images, this study attempted to determine changes in vegetation cover in The Gambia over the period 2000-2019. The results showed an increasing trend in vegetation productivity between 2000 and 2009 in almost all regions. It is also significant from north to south along the river. In contrast, in the decade 2010-2019, there was a general downward trend in productivity in $44.01 \%$ of the study area, but less pronounced in the western part of the Lower River Region, West Coast Region and Banjul. The calculation of the Kendall correlation over the period studied indicated that 59.2 per cent of the national territory was marked by a positive trend and 40.8 per cent by a negative trend. Over the entire study period (2000-2019), the Kendall correlation calculation indicated that $59.2 \%$ of the national territory is marked by a positive trend and $40.8 \%$ by a negative trend. The percentage of significant positive trend is $10 \%$, the negative one is $4 \%$.

This study is important in that it brings new knowledge to decision makers in relation to the existing knowledge on changes in vegetation cover in The Gambia. It allows for more accurate identification of the different trends that are taking place and the main determinants of these trends, which are necessary for the development of effective forest resource management policies. However, despite the effectiveness of the methodological approach used, it would be useful in the future to include, field data, land use and land cover data, and spatialized precipitation data in the analysis.

\section{BIBLIOGRAPHY}

AKON-YAMGA G., BOADU P., OBIRI B.D., AMOAKO J. \& MBOOB F.J. (2011), “Agricultural Innovations for Climate Change Adaptation and Food Security in Africa: The Cases of Ghana and The Gambia", African Technology Policy Studies Network, 10, 11, pp. 1-56.

ANDRIEU J. (2018), “Analysis of the kinematics of vegetation in Ivory Coast during conflicts through phenological metric and Kendall correlation of two NDVI time series", Tropicultura, 36, 2, pp. 258-270.

ANDRIEU J., MERING C. (2008), "Mapping by remote sensing of changes in vegetation cover on the West African coastal strip: example of rivers from the southern Saloum Delta (Senegal) to the Gêba River (Guinea-Bissau)", Télédétection, 8, 2, pp. 93-118.

ARIORI S.L., OZER P. (2005), "Evolution of Forest Resources in Sudano-Sahelian West Africa over the last 50 years", Geo-Eco-Trop, pp. 61-68. 
BAH O.L., KONE T., YAFFA S. \& NDIAYE M.L. (2019), "Land Use and Land Cover Dynamics in Central River Region of The Gambia, West Africa from 1984 to 2017”, American Journal of Modern Energy, 5, 2, pp. 5-18.

BOJANG P.O., YU P., YANG T. \& KUO C. (2016), “Optimal cropping patterns for profit maximization using a linear programming model: A case study in Njawara Village”, The Gambia, pp. 10-13.

BRANDT M., HIERNAUX P., RASMUSSEN K., MBOW C., KERGOAT L., TAGESSON T., IBRAHIM Y.Z., WELE A., TUCKER C.J. \& FENSHOLT R. (2016), “Assessing woody vegetation trends in Sahelian drylands using MODIS based seasonal metrics", Remote Sensing of Environment, 183, pp. 215-225

CIESIN (2005), Gridded population of the world version 3 (GPWV3): population density grids, Palisades, NY, Columbia University, Socioeconomic Data and Applications Center (SEDAC), http:// sedac.ciesin.columbia.edu/gpw, accessed January 11, 2016.

CILSS (2016), The Landscapes of West Africa: A Window on a Changing World, U.S. Geological Survey EROS, $47914252^{\text {nd }}$ St, Garretson, SD 57030, United States, 219 p.

CISSE S. (2016), Study of intra-seasonal variability in precipitation in the Sahel: impacts on vegetation (Ferlo in Senegal), PhD thesis from Pierre et Marie Curie-Paris VI University, $160 \mathrm{p}$.

DARDEL C., KERGOAT L., HIERNAUX P., MOUGIN E., GRIPPA M. \& TUCKER C.J. (2014), “Regreening Sahel: 30 years of remote sensing data andfield observations (Mali, Niger)", Remote Sensing of Environment, 140, pp. 350-364.

DIEDHIOU I., MERING C., SY O. \& SANE T. (2020), “Mapping land use and land change by remote sensing: Application to the analysis of the dynamics of Senegal's forest landscapes between 1972 and 2016", EchoGéo, 54, pp. 1-41.

DIEDHIOU I. (2019), Between the use and preservation of woody resources in West Africa: Forest landscape dynamics in southern Senegal, $\mathrm{PhD}$ thesis in co-tutorship of the University of Paris and Assane Seck University of Ziguinchor, Senegal, $444 \mathrm{p}$.

DIEYE E.H.B., SANE T., SOLLY B., DIEDHIOU P., BA B.D., THIOR M., MERING C., SY O. \& DIAW A.T. (2021), "Spatial dynamics and socio-environmental changes in the West African mangrove zone, from the Joal-Fadiouth lagoon (Senegal) to the Rio de Cacine (Guinea-Bissau)", Proceedings of the LMI-PATEO-UASZ International Symposium, held at the Assane Seck University of Ziguinchor (Senegal) from 19 to 22 November 2019, pp. 547-562.

ECKERT S., HUSLER F., LINIGER H. \& HODEL E. (2015), "Trend analysis of MODIS NDVI time series for detecting land degradation and regeneration in Mongolia", Journal of Arid Environments, 113, pp. 16-28.

FAO (2015), Global Forest Resources Assessment 2015, FRA Data Directory, Rome, Italy, 244 p.

FENSHOLT R. (2004), "Earth observation of vegetation status in the Sahelian and Sudanian West Africa: comparison of Terra MODIS and NOAA AVHRR satellite data", International Journal of Remote Sensing, 25, 9, pp. 1641-1659.

FENT A., BARDOU R., CARNEY J. \& CAVANAUGH K. (2019), “Transborder political ecology of mangroves in Senegal and The Gambia", Global Environmental Change, 54, pp. 214-226.

GANSAONRE R.N., ZOUNGRANA B.J.-B. \& YANOGO P.I. (2020), "Vegetation cover dynamics on the outskirts of the W Park of Burkina Faso", Belgeo, 1, pp. 1-23.

GUO M., LI J., HE H., XU J. \& JIN H. (2018), “Detecting Global Vegetation Changes Using MannKendal (MK) Trend Test for 1982-2015 Time Period”, Chinese Geographical Science, 28, pp. 907-919. 
HERRMANN S.M., ANYAMBA A. \& TUCKER C.J. (2005), "Recent trends in vegetation dynamics in the African Sahel and their relationship to climate", About Global Change, 15, pp. 394-404.

HAMIMINA G., DUFRÊNE E., PONTAILLER J.-Y., DELPIERRE N., AUBINET M., CAQUET B. \& SOUDANI K. (2013), "Evaluation of the potential of MODIS satellite data to predict vegetation phenology in different biomes: An investigation using ground-based NDVI measurements", Remote sensing of environment, 132, pp. 145-158.

HOUNTONDJI Y-C.H. (2008), Environmental dynamics in the Sahelian and Sudanian zones of West Africa: Analysis of changes and assessment of degradation of vegetation cover, $\mathrm{PhD}$ thesis in Science and Environmental Management from the University of Liège, $181 \mathrm{p}$.

JARJU A.M., SOLLY B. \& SONKO E. (2021), "Rainfall variability and agricultural production in the Lower River Region (Gambia): case of rice and maize", International Journal of Innovation and Scientific Research, 52, 2, pp. 178-184.

LEROUX L., BEGUE A. \& LO SEEN D. (2014), "Regional analysis of Crop and Natural Vegetation in West Africa based on NDVI metrics", in IEEE (ed.), IEEE International Geoscience \& Remote Sensing Symposium, Québec, Canada, pp. 5107-5110.

LOUM A., FOGARASSY C. (2015), "The effects of climate change on cereals yield of production and food security in Gambia”, APSTRACT: Applied Studies in Agribusiness and Commerce, 9, 4, pp. 83-92.

MINISTRY OF ENVIRONMENT, CLIMATE CHANGE AND NATURAL RESOURCES, (2018), The Gambia Land Degradation Neutrality National Report, Republic of The Gambia, 33 p.

MISHRA N.B., MAINALI K.P. (2017), “Greening and browning of the Himalayas: Spatial patterns and the role of climate change and human drivers", Science of the Total Environment, pp. 326-339.

NEETI N., EASTMAN J.R. (2011), “A Contextual Mann-Kendall Approach for the Assessment of Trend Significance in Image Time Series”, Transactions in GIS, 15, 5, pp. 599-611.

NICHOLSON S.E., DAVENPORT M.L. \& MALO A.R. (1990), “A comparison of the vegetation response to rainfall in the Sahel and East Africa using normalized difference vegetation index from NOAA AVHRR", Climatic Change, 17, pp. 209-241.

PHILIPPON N., MARTINY N., CAMBERLIN P. \& RICHARD Y. (2008), "Impact of precipitation on photosynthetic vegetation activity in sub-Saharan semi-arid Africa”, Climatology Days - Nantes, 13-14 March 2008, Climate and society: Climate and vegetation, pp. 77-90.

SAN EMETERIO J-L., LACAZE B. \& MERING C. (2011), "Detection of changes in vegetation cover in the Sahel during the period 1982-2002 from NDVI data and precipitation”, Remote sensing, 10, 2-3, pp. 135-143.

SANNEH E.S., HU A.H., HSU C.W. \& NJIE M. (2014), "Prioritization of climate change adaptation approaches in The Gambia", Mitigation and Adaptation Strategies for Global Change, 19, 8, pp. $1163-1178$

SOLLY B., DIEYE E.H.B., SY O., JARJU A.M. \& SANE T. (2021), "Detection of areas of degradation and regeneration of vegetation cover in southern Senegal through analysis of the trends of the MODIS NDVI time series and changes in land use with Landsat", French Journal of Photogrammetry and Remote Sensing, 223, pp. 1-15.

SONKO E., AGODZO S.K. \& ANTWI-AGYEI P. (2019), "Evaluating the Yield Response of Maize (Zea mays L.) and Rice (Oryza sativa L.) to Future Climate Variability in The Gambia" Journal of Agricultural Studies, 7, 2, pp. 11-26. 
WESSELS K.J., BERGH F.V.D. \& SCHOLES R.J. (2012), "Limits to detectability of land degradation by trend analysis of vegetation index data", Remote sensing of environment, 125, pp. 10-22.

YAFFA S. (2013), "Coping measures not enough to avoid loss and damage from drought in the North Bank Region of The Gambia", International Journal of Global Warming, 5, 4, pp. 467-482.

YENGOH G.T., DENT D., OLSSON L., TENGBERG A.E. \& TUCKER III C.J. (2015), Use of the Normalized Difference Vegetation Index (NDVI) to Assess Land Degradation at Multiple Scales Current Status, Future Trends, and Practical Considerations, SpringerBriefs in Environmental Science, $110 \mathrm{p}$.

ZOUNGRANA B.J-B., CONRAD C., THIEL M., AMEKUDZI L.K. \& DA E.D. (2018), “MODIS NDVI trends and fractional land cover change for improved assessments of vegetation degradation in Burkina Faso, West Africa", Journal of Arid Environments, 153, pp. 66-75.

\section{ABSTRACTS}

In The Gambia, the vegetation cover has undergone significant changes over the past two decades. To assist policy decision-making, this study seeks to detect trends in changes over the past two decades using a time series of NDVI MODIS images. The methodological approach is based on the calculation of the correlation of Kendall $(\tau)$ associated with the p-significance test at the $10 \%$ threshold. The results showed a trend of increasing vegetation productivity during the decade $2000-2009$ (98.37\% of the study area) in almost all administrative regions. This trend is more significant along the river. In contrast, during the decade 2010-2019, it was noted overall significant downward trend in productivity (44.01\% of The Gambia) in all administrative regions except West Coast Region and Banjul, however not significant. The result showed that, over the whole period (2000-2019), 61.86\% of the national territory was characterized by a positive trend and $38.14 \%$ by a negative trend; and that the significant positive trend percentage is $10 \%$, the significant negative trend percentage is $4 \%$. Significant positive trends are observed much more along the river and central of the Central River Region; significant negative trends are observed mainly in the western part of West Coast Region and Banjul, at the eastern end of the North Bank Region and in the Upper River Region.

En Gambie, la couverture végétale connait d'importantes modifications depuis les deux dernières décennies. Pour aider les politiques dans leur prise de décision, cette étude cherche à détecter les tendances des changements au cours de cette période à l'aide d'une série temporelle d'images MODIS NDVI. L'approche méthodologique est basée sur le calcul de la corrélation de Kendall $(\tau)$ associé au test de significativité de $\mathrm{p}$ au seuil de $10 \%$. Les résultats ont montré une tendance à l'augmentation de la productivité de la végétation durant la décennie 2000-2009 (98,37\% de la zone d'étude) dans quasiment toutes les régions administratives. Cette tendance est plus significative le long du fleuve. Par contre, durant la décennie 2010-2019, on a noté globalement d'importantes tendances à la baisse de la productivité (44,01\% de la Gambie) dans toutes les régions administratives excepté la West Coast Region et Banjul, toutefois non significatives. À l'échelle de toute la période étudiée (2000-2019), 61,86\% du territoire national est marqué par une tendance positive et $38,14 \%$ par une tendance négative. Le pourcentage de tendance positive significative est de $10 \%$, celui significativement négatif de $4 \%$. Les tendances positives significatives sont le plus souvent observées le long du fleuve et dans le centre de la Central River Region, celles significativement négatives principalement dans la partie ouest de la West Coast Region et de Banjul, à l'extrémité Est de la North Bank Region et de la Upper River Region. 
INDEX

Mots-clés: MODIS-NDVI, analyse des tendances, tau de Kendall, couverture végétale, Gambie Keywords: MODIS-NDVI, trend analysis, Kendall tau, vegetation cover, The Gambia

\section{AUTHORS}

\section{BOUBACAR SOLLY}

Department of Geography, Geomatics and Environment Laboratory, Assane Seck University of Ziguinchor, Sénégal, b.solly1087@zig.univ.sn

ARUNA M. JARJU

Academic Support Coordinator King Graduate School-Monroe College, New York, USA, ajarju@monroecollege.edu

\section{EBRIMA SONKO}

Director of Crop Research, National Agricultural Research Institute, Brikama-The Gambia, sonko.e@edu.wascal.org

\section{SIDAT YAFFA}

Director of UTG/WASCAL Doctoral Research Program on Climate Change and Education; School of Agriculture and Environmental Sciences, University of The Gambia, syaffa@utg.edu.gm

\section{MAMMA SAWANEH}

School of Agriculture and Environmental Sciences, University of The Gambia, msawaneh@utg.edu.gm 